\title{
Improving Pedagogical Mechanisms to Increase Special Physical Preparation of Students with Disabilities in Uzbekistan
}

\author{
Mexriddin Mirjamolov Khayriddinovich ${ }^{1}$,Neila Svetlichnaya Kamilovna ${ }^{2}$, Sherzod \\ Abdiev Abdirahmonovich ${ }^{3}$,Lola Davlatova Tilopovna ${ }^{4}$,Laylo Sobirova Bakhromovna ${ }^{5}$ \\ ${ }^{1}$ Head of the Department of Adaptive Physical Culture and Sports of UzSUPCS Doctor of \\ Philosophy in Pedagogical Sciences (PhD), Associate Professor \\ ${ }^{2}$ UzSUPCS Department of Adaptive Physical Education and Sports, Associate Professor, \\ ${ }^{3}$ Senior Lecturer, Department of Adaptive Physical Education and Sports of UzSUPCS \\ ${ }^{4}$ Teacher of the Department of Adaptive Physical Education and Sports of UzSUPCS \\ ${ }^{5}$ Teacher of the Department of Adaptive Physical Education and Sports of UzSUPCS Doctor \\ of Philosophy in Pedagogical Sciences (PhD)
}

\begin{abstract}
This article reveals ways to improve the pedagogical abilities of the educational process, which is carried out with students with disabilities. The body is studied on the basis of the laws of fast and long-term coupling with physical activity, principles and laws of sports training developed in the theory of sports. A differentiated training program on mobility practices was recommended for practical training. The possibilities of rational organization in accordance with the legislation of the formation of education, knowledge, skills and mobility in the process of adaptive physical education are studied.
\end{abstract}

Keywords: development of motor capabilities, special physical training, limited physical ability, distribution and regulation of loads, functional capabilities of persons with disabilities, treatment and rehabilitation, posture formation, a specially developed program.

Article Received: 16th October, 2020; Article Revised: 30th December, 2020; Article Accepted: 08th January, 2021

Relevance. In our country, great attention is paid to addressing social issues, in particular, issues related to disability. As noted by the President of the Republic of Uzbekistan Shavkat Mirziyoyev, Every privilege and social protection measure must reach its owner."

The level of physical fitness of students, hygiene, medical control, sports medicine, self-control and other issues set in the state program determine the set of requirements for their professional and practical physical training. In this regard, increasing the special physical capacity of college students with disabilities is one of the components of scientific research in our country.

"Scientific and methodological recommendations on sports psychology, dietetics, rehabilitation and medicine, manuals, preparation and publication of textbooks, effective science-based tools and methods for the development of mass sports and promotion of a healthy lifestyle among the population. Development "is one of our urgent tasks.

According to the analysis, although research has been conducted on the training of students with disabilities and physical disabilities, the specifics of selecting and applying exercises based on a specific program for college students with musculoskeletal disorders have not been sufficiently studied. An analysis of the physical education program for students with disabilities and physical disabilities revealed that no specific physical development exercises and standards for disability have been developed, and the characteristics of disability have not been taken into account. 


\section{Analysis of the relevant literature}

MV Devyatova, TU Ismailov on the issues of accelerating the socialization of the disabled and people with disabilities, NK Svetlichnaya, EA Urinbaev, VB Aripova and $[14,15,18,3]$ A.Abele, H.Arends, Age limits on the development of physical qualities in the classification of many types of musculoskeletal injuries by foreign scientists in many countries around the world. K. Armor and M. Yelling, scientific and methodological aspects of improving physical fitness E. Balz, T. Benn, H. Brandl-

Bredenbeck, W.Brettschneider, Costa, B.Crum, and H.Stegeman in F.Carreiro, Features of Improving Sports Performance, P.De Knop, M.Theeboom, K.Huts, and others have studied the issues of mood management in training. [1, $4,6,8,9,10,11,12]$

Among the leading scientists in Russia and the CIS countries on the specifics of improving the effectiveness of training of persons with disabilities in the field of education: N. G.Astafeva, Yu. A.Kobzev, V. V.Xramov, L. A.Boyarskaya, L. G.Xaritonova, S. I.Venevtsev, O. L. Zhukova, I. on the effectiveness of the use of new technologies in adaptive physical education. V.Erkomashvili, A.Sazonov, A.S. Solodkov and OV Morozova, Vinogradov GP, Yashina TD, AIDyachkov, SD Antonyuk on improving the psychological readiness and functional performance in education, $S$ on the main factors in the development of motor skills of students with disabilities. .A.Korolyov, L.V.Shapkova, S.P. Researched by Evseev, Gapparov Z.G.,Ishtaev J.M., Ishtaev D.R., Holmurodov L.Z. et al. $[2,7,21,16,19,20,21,22]$

The modern trend of integrating curricula as a whole within the framework of higher education (between majors and programs of different specialties), as well as within the framework of interaction between higher and secondary special schools, is interrelated with a number of objective factors. According to SP Evseev, training in joint programs (e.g., direction and specialization) allows for vocational training, which makes them more secure and competitive in the labor market.

In addition, the harmonized and joint implementation of higher and secondary special vocational education programs will reduce the time of their acquisition, eliminate duplication of teaching materials, improve interdisciplinary communication. [1,4,5,6,8, 9,10,11,12]

Many scientists have made suggestions on the use of therapeutic gymnastics as a promising direction for the restoration of lost function in the case of musculoskeletal injuries. Possibilities of maximum adaptation of movement, independent movement, and self-service were explored. Focusing on the issues of restoring the lost functional capabilities of students with physical disabilities through the correct application of the norms and number of repetitions of exercise.

However, despite the positive changes in the organization of public services in the rehabilitation of the disabled, individual programs and assessment mechanisms for independent practice of physical education in colleges by types and levels of disability have not been scientifically substantiated. The aim of the study is to develop a differentiated program aimed at restoring body functions based on the study of functional and physical fitness indicators of students with disabilities.

Research methods: study and analysis of scientific and methodological literature, pedagogical observation, pedagogical control, pedagogical testing, analysis of physiological processes (Robinson index to determine the energy potential of the body), pedagogical experience, mathematical and statistical methods.

\section{Research methodology}

The main requirement in the assessment of physical culture and sports is to recommend to each subject to engage in this or that sport, an individual approach, taking into account its physiological characteristics, level of health.

The study included 4 interrelated stages. Stage 1 - study and analysis of scientificmethodical and specialized literature on 
the problem under study, the formation of research hypotheses and tasks.

Stage 2 - the formation of a scientific basis for the content and methodology of teaching aids, based on the specifics of physical education with students with disabilities;-

Stage 3 - substantiation in pedagogical practice of the effectiveness of the program aimed at the restoration of adaptive physical education for different levels of musculoskeletal injuries;-
Step 4 - processing the data obtained, writing the text of the work and approbating it.- The program proposed by us allows for differentiated training of different forms of musculoskeletal injuries, as the program sections are structured based on the mobility capabilities of the trainees (see Table 1). This, in turn, served to increase the activity of students by ensuring that the lessons were interesting and meaningful.

Table 1

A circle training program designed for various forms of musculoskeletal injuries

\begin{tabular}{|c|c|c|c|c|c|c|c|c|c|c|c|c|c|c|}
\hline \multirow{2}{*}{ № } & \multirow[t]{2}{*}{ Software sections } & \multirow{2}{*}{$\begin{array}{l}\text { Annual } \\
\text { hourly } \\
\text { plan }\end{array}$} & \multicolumn{4}{|c|}{ I half year } & \multirow[t]{2}{*}{$\begin{array}{l}\text { Total } \\
\text { hours }\end{array}$} & \multicolumn{6}{|c|}{ II half year } & \multirow[t]{2}{*}{$\begin{array}{l}\text { Total } \\
\text { hours }\end{array}$} \\
\hline & & & IX & $\mathrm{X}$ & $\mathrm{XI}$ & $\mathrm{XII}$ & & $\mathrm{I}$ & II & III & IV & $\mathrm{V}$ & VI & \\
\hline \multicolumn{15}{|c|}{ Training program for amputee forms of musculoskeletal system } \\
\hline 1 & Fitball gymnastics & 20 & 2 & 2 & 2 & 2 & \begin{tabular}{|l|l|l}
8 & \\
\end{tabular} & 2 & 2 & 2 & 2 & 2 & 2 & 12 \\
\hline 2 & $\begin{array}{l}\text { Bodybuilding } \\
\text { exercises }\end{array}$ & 10 & & & & & 0 & 2 & 2 & 2 & 2 & 2 & & 10 \\
\hline 3 & Homework exercises & 8 & 2 & 2 & & & 4 & & & & & 2 & 2 & 4 \\
\hline 4 & $\begin{array}{l}\text { Targeting anc } \\
\text { balance exercises }\end{array}$ & 26 & 2 & 2 & 2 & 2 & 8 & 2 & 4 & 4 & 4 & 2 & 2 & 18 \\
\hline 5 & $\begin{array}{l}\text { Climbing and } \\
\text { jumping exercises }\end{array}$ & 8 & & & & & 0 & 2 & 2 & 2 & 2 & & & 8 \\
\hline 6 & $\begin{array}{l}\text { Exercises performed } \\
\text { with a large tenni, } \\
\text { ball }\end{array}$ & 4 & & 2 & 2 & & 4 & & & & & & & 0 \\
\hline 7 & $\begin{array}{l}\text { Exercises performed } \\
\text { with a filling ball (1.5 } \\
\mathrm{kg})\end{array}$ & 4 & & & & & 0 & & & & & 2 & 2 & 4 \\
\hline 8 & Jumping exercises & 4 & & & 2 & 2 & 4 & & & & & & & 0 \\
\hline 9 & $\begin{array}{l}\text { Exercises in the } \\
\text { description of the } \\
\text { game, a variety o } \\
\text { games with no tims } \\
\text { limit }\end{array}$ & 12 & & & & & 0 & 2 & 2 & 2 & 2 & 2 & 2 & 12 \\
\hline 10 & The sport of choice & 40 & 6 & 4 & 4 & 2 & 16 & 4 & 4 & 4 & 4 & 4 & 4 & 24 \\
\hline 11 & Synovar control & 8 & & & & 4 & 4 & 2 & & & & & 2 & 4 \\
\hline 12 & Total hours & 144 & 12 & 12 & 12 & 12 & 48 & 16 & 16 & 16 & 16 & 16 & 16 & 96 \\
\hline \multicolumn{15}{|c|}{ Training manual for minor degrees of musculoskeletal disorders } \\
\hline 1 & $\begin{array}{lr}\begin{array}{lr}\text { Exercises } \\
\text { improve } \\
\text { circulation }\end{array} & \text { bloo } \\
\end{array}$ & 38 & 4 & 6 & 8 & 8 & 26 & 2 & 2 & 2 & 2 & 2 & 2 & 12 \\
\hline 2 & $\begin{array}{l}\text { Exercises } \\
\text { promote balance }\end{array}$ & 16 & & & 2 & 2 & 4 & 2 & 2 & 2 & 2 & 2 & 2 & 12 \\
\hline 3 & Fitball gymnastics & 30 & 2 & 2 & 2 & & 6 & 2 & 4 & 4 & 4 & 4 & 6 & 24 \\
\hline 4 & Stretching exercises & 4 & 2 & 2 & & & 4 & & & & & & & 0 \\
\hline
\end{tabular}




\begin{tabular}{|c|c|c|c|c|c|c|c|c|c|c|c|c|c|c|}
\hline 5 & $\begin{array}{l}\text { Exercises performed } \\
\text { in pairs }\end{array}$ & 14 & 2 & 2 & & & 4 & 2 & 2 & 2 & 2 & 2 & & 10 \\
\hline 6 & Rotational exercise & 10 & & & & & 0 & 2 & 2 & 2 & 2 & 2 & & 10 \\
\hline 7 & $\begin{array}{l}\text { Exercises performed } \\
\text { on the simulator and } \\
\text { other devices. }\end{array}$ & 12 & & & & & & 2 & 2 & 2 & 2 & 2 & 2 & 12 \\
\hline 8 & \begin{tabular}{l|l} 
Games & \\
\end{tabular} & 12 & & & & & 0 & 2 & 2 & 2 & 2 & 2 & 2 & 12 \\
\hline 9 & $\begin{array}{l}\text { Evaluate movemen } \\
\text { activity }\end{array}$ & 8 & 2 & & & 2 & 4 & 2 & & & & & 2 & 4 \\
\hline 10 & Total hours & 144 & 12 & 12 & 12 & 12 & 48 & 16 & 16 & 16 & 16 & 16 & 16 & 96 \\
\hline \multicolumn{15}{|c|}{ In cerebral palsy(ICP) training program at } \\
\hline 1 & $\begin{array}{lr}\begin{array}{l}\text { Exercises } \\
\text { improve } \\
\text { circulation. }\end{array} & \text { bloos } \\
\end{array}$ & 12 & 4 & 2 & 2 & & 8 & 2 & 2 & & & & & 4 \\
\hline 2 & Climbing exercises & 24 & 2 & 2 & 2 & 2 & 8 & 2 & 2 & 2 & 2 & 4 & 4 & 16 \\
\hline 3 & $\begin{array}{lr}\begin{array}{l}\text { Exercises } \\
\text { strengthen } \\
\text { muscles }\end{array} & \text { differen } \\
\end{array}$ & 16 & & 2 & 2 & 4 & 8 & 2 & 2 & 2 & 2 & & & 8 \\
\hline 4 & $\begin{array}{l}\text { Exercises with the } \\
\text { ball }\end{array}$ & 8 & & & & & 0 & & & 2 & 2 & 2 & 2 & 8 \\
\hline 5 & Fitball gymnastics & 32 & 2 & 2 & 2 & 2 & 8 & 4 & 4 & 4 & 4 & 4 & 4 & 24 \\
\hline 6 & $\begin{array}{l}\text { Exercises performed } \\
\text { on the simulator and } \\
\text { other devices }\end{array}$ & 20 & & & 2 & 2 & 4 & 2 & 2 & 4 & 4 & 2 & 2 & 16 \\
\hline 7 & Targeting exercises & 12 & 2 & 2 & & & 4 & & 2 & 2 & 2 & 2 & & 8 \\
\hline 8 & $\begin{array}{l}\text { Exercises performed } \\
\text { with a large ball }\end{array}$ & 12 & & 2 & 2 & & 4 & 2 & 2 & & & 2 & 2 & 8 \\
\hline 9 & $\begin{array}{l}\text { Evaluation } \\
\text { movement activity }\end{array}$ & 8 & 2 & & & 2 & 4 & 2 & & & & & 2 & 4 \\
\hline 10 & Total hours & 144 & 12 & 12 & 12 & 12 & 48 & 16 & 16 & 16 & 16 & 16 & 16 & 96 \\
\hline
\end{tabular}

Note: Classes in the physical education circle are held 2 times a week for 2 hours according to the program

As a result of the research, the content of the theory and practice of physical education for students with disabilities was enriched and systematized on the basis of modern requirements.

In the distribution of monthly and weekly means of conducting training on the basis of the program developed by us, more emphasis was placed on training for circulatory-improving exercises, fitball gymnastics and the selected sport (see Table 2).

The weekly program of training for various forms of musculoskeletal injuries clearly defined the direction of action of the tools, the duration of the exercise, the number of heartbeats in each exercise, training intensity, rest time and number of repetitions of exercises (see Table 3 ).

\section{Table 2}

Distribution of monthly means (in \% of the total volume) designed for different forms of musculoskeletal injuries

\begin{tabular}{|l|l|l|l|l|l|l|}
\hline \multirow{2}{*}{ № } & Software sections & \multicolumn{2}{|l|}{ Weeks } & \multirow{2}{*}{ Total } \\
\cline { 3 - 5 } & & I & II & III & IV & \\
\hline \multicolumn{2}{|l|}{ Training program for amputation of musculoskeletal injuries } \\
\hline 1 & Fitball gymnastics & 5 & 4 & 5 & 4 & 18 \\
\hline
\end{tabular}




\begin{tabular}{|l|l|l|l|l|l|l|}
\hline 2 & Homework exercises & 4 & 4 & 4 & 4 & 16 \\
\hline 3 & Targeting and balance exercises & 4 & 4 & 4 & 4 & 16 \\
\hline 4 & Elective sport & 12.5 & 12.5 & 12.5 & 12.5 & 50 \\
\hline Training program for mild levels of musculoskeletal injuries \\
\hline 5 & Exercises that improve blood circulation & 8 & 8 & 8.3 & 9 & 33.3 \\
\hline 6 & Fitball gymnastics & 4 & 4 & 4 & 4.7 & 16.7 \\
\hline 7 & Stretching exercises & 4 & 4 & 4 & 4 & 16 \\
\hline 8 & $\begin{array}{l}\text { Exercises to develop mutual support for } \\
\text { each other }\end{array}$ & 4 & 4 & 4 & 4 & 16 \\
\hline 9 & Evaluation of movement activity & 4 & 4 & 4 & 4 & 16 \\
\hline A program for the treatment of cerebral palsy & \multicolumn{5}{|l|}{} \\
\hline 10 & Exercises that improve blood circulation & 8 & 8 & 8.3 & 9 & 33.3 \\
\hline 11 & Climbing exercises & 4 & 4 & 4 & 4.7 & 16.7 \\
\hline 12 & Fitball gymnastics & 4 & 4 & 4 & 4 & 16 \\
\hline 13 & Targeting exercises & 4 & 4 & 4 & 4 & 16 \\
\hline 14 & Evaluation of movement activity & 4 & 4 & 4 & 4 & 16 \\
\hline
\end{tabular}

The training load given in the program was changed depending on the level of exposure to the body of the trainees. In the training, mainly large loads were selected and carried out with small intensities. Loads have led to the provision of optimal conditions for recovery and adaptation in the body. Their main purpose is to stimulate the processes of adaptation in the body, to solve the main problems of technical-tactical, physical, volitional, special mental training.

Table 3

Training for various forms of musculoskeletal injuries weekly schedule

\begin{tabular}{|c|c|c|c|c|c|c|c|}
\hline 总 & "̄o & .气 & 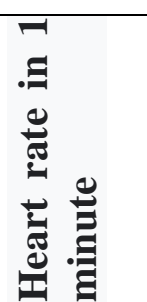 & 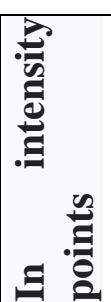 & 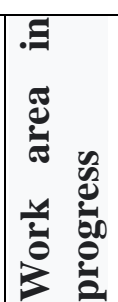 & 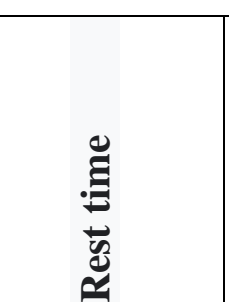 & 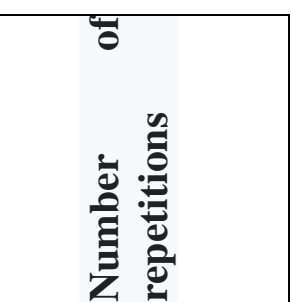 \\
\hline \multicolumn{8}{|c|}{ Program of training in the form of amputation of musculoskeletal injuries } \\
\hline $\begin{array}{l}\text { Fitball } \\
\text { gymnastics }\end{array}$ & $\begin{array}{l}\text { Higher that } \\
\text { aerobics }\end{array}$ & $\begin{array}{l}20-30 \\
\text { minutes. } \\
\text { and } \\
\text { more }\end{array}$ & 130-140 & $4-6$ & I & $\begin{array}{l}0.5 \text { minute } \\
\text { between } \\
\text { exercises. } \\
\text { min betweer } \\
\text { series. }\end{array}$ & $\begin{array}{l}\text { A series of 6-8 } \\
\text { exercises, } \\
\text { repeated } \\
\text { times }\end{array}$ \\
\hline $\begin{array}{l}\text { Shape the } \\
\text { stature } \\
\text { face exercises }\end{array}$ & Aerob & $\begin{array}{l}\text { Up } \\
20-30 \\
\text { minutes }\end{array}$ & 132-138 & 4 & I & $05-1.5 \mathrm{~min}$ & $\begin{array}{|lrr|}\text { In } & \text { repetitive } \\
\text { work } & 10 & \text { and } \\
\text { more } & \text { in } & 2-4 \\
\text { series } & & \\
\end{array}$ \\
\hline $\begin{array}{l}\text { Homework } \\
\text { exercises }\end{array}$ & $\begin{array}{l}\text { Mixed } \\
\text { aerobic- } \\
\text { anaerobic }\end{array}$ & $\begin{array}{l}\text { Up } \\
10-20 \\
\text { minutes }\end{array}$ & 156-168 & $8-12$ & II & $\begin{array}{l}0.5 \text { minute } \\
\text { between } \\
\text { exercises. }\end{array}$ & $\begin{array}{l}\text { A series of 5-6 } \\
\text { exercises, } \\
\text { repeated } \\
\text { times }\end{array}$ \\
\hline $\begin{array}{l}\text { Targeting and } \\
\text { balance } \\
\text { exercises }\end{array}$ & $\begin{array}{l}\text { Mixed } \\
\text { aerobic- } \\
\text { anaerobic }\end{array}$ & $\begin{array}{l}\text { Up to } \\
20-30 \\
\text { minutes }\end{array}$ & 138-144 & $5-6$ & I & $1-2 \mathrm{~min}$ & $\begin{array}{l}10 \text { and more } 2-4 \\
\text { in a one-tim } \\
\text { repetitive study }\end{array}$ \\
\hline
\end{tabular}




\begin{tabular}{|c|c|c|c|c|c|c|c|}
\hline $\begin{array}{l}\text { Climbing and } \\
\text { jumping } \\
\text { exercises }\end{array}$ & $\begin{array}{l}\text { Mixed } \\
\text { aerobic- } \\
\text { anaerobic }\end{array}$ & $\begin{array}{l}\text { Up } \\
20-30 \\
\text { minutes }\end{array}$ & $156-162$ & $8-10$ & II & $\begin{array}{l}0.5 \text { minute } \\
\text { between } \\
\text { exercises. } \\
\text { min between } \\
\text { series. }\end{array}$ & $\begin{array}{l}3 \text { or more in } \\
\text { one-time } \\
\text { repetitive study }\end{array}$ \\
\hline $\begin{array}{l}\text { Exercises } \\
\text { performed with } \\
\text { a large tennis } \\
\text { ball }\end{array}$ & $\begin{array}{l}\text { Mixed } \\
\text { aerobic- } \\
\text { anaerobic }\end{array}$ & $\begin{array}{l}20-40 \\
\text { minutes }\end{array}$ & 168-174 & $12-14$ & II & $\begin{array}{l}1-2 \text { minute } \\
\text { between } \\
\text { exercises. } \\
\text { min between } \\
\text { series. }\end{array}$ & $\begin{array}{l}\text { A series of 8-10 } \\
\text { exercises, } \\
\text { repeated } \\
\text { times }\end{array}$ \\
\hline $\begin{array}{ll}\text { Exercises } & \\
\text { performed with } \\
\text { a filling bal } \\
(1.5 \mathrm{~kg})\end{array}$ & $\begin{array}{l}\text { Higher thar } \\
\text { aerobics }\end{array}$ & $\begin{array}{l}15-20 \\
\text { minutes } \\
\text { and } \\
\text { more }\end{array}$ & $144-150$ & 6-7 & I & $1-2 \min$ & \begin{tabular}{lrr} 
In & \multicolumn{2}{c}{ repetitive } \\
work & 10 & an \\
more & in & $2-$ \\
series & & \\
\end{tabular} \\
\hline $\begin{array}{l}\text { Jumping } \\
\text { exercises }\end{array}$ & $\begin{array}{l}\text { Mixed } \\
\text { aerobic- } \\
\text { anaerobic }\end{array}$ & $\begin{array}{l}15-20 \\
\text { minutes } \\
\text { and } \\
\text { more }\end{array}$ & $156-162$ & $8-10$ & II & $\begin{array}{l}1-2 \text { minute } \\
\text { between } \\
\text { exercises. } \\
\text { min between } \\
\text { series. }\end{array}$ & $\begin{array}{l}\text { A series of 2-4 } \\
\text { exercises, } \\
\text { repeated } \\
\text { times }\end{array}$ \\
\hline $\begin{array}{l}\text { Game } \\
\text { description } \\
\text { exercises and } \\
\text { variety } \\
\text { games }\end{array}$ & $\begin{array}{l}\text { Mixed } \\
\text { aerobic- } \\
\text { anaerobic }\end{array}$ & $\begin{array}{l}15-20 \\
\text { minutes } \\
\text { and } \\
\text { more }\end{array}$ & $156-162$ & $8-10$ & II & $\begin{array}{l}\text { Unlimited, } \\
\text { moody } \\
\text { repetitive } \\
\text { work }\end{array}$ & $\begin{array}{lr}\text { It } & \text { varie } \\
\text { depending or } \\
\text { the physica } \\
\text { ability of the } \\
\text { students }\end{array}$ \\
\hline Elective sport & $\begin{array}{l}\text { Anaerobic- } \\
\text { glycolytic }\end{array}$ & $\begin{array}{l}40-50 \\
\text { minutes } \\
\text { and } \\
\text { more }\end{array}$ & 180-192 & $17-25$ & II- III & $\begin{array}{l}\text { According to } \\
\text { the rules }\end{array}$ & 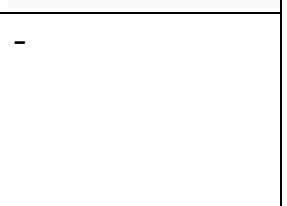 \\
\hline
\end{tabular}

The results obtained by us after training based on a program designed to improve motor activity showed a positive dynamics of indicators such as rapid fatigue, intensifying the process of elimination of locomotor disorders of movement. Exercisers were able to sit and work longer, and sensitivity and irritability decreased.

The processes of self-control are somewhat intensified. It was noted that movement (almost 90.0\%, and sensory development in $80 \%$ of cases) was delayed in students with musculoskeletal disorders until the scientific experiment, and the remaining indicators were also found to be below normal. In the experimental group of students, developmental delay after fitball gymnastics (FG) included in the program decreased by 1.8 times (55\%) compared to pre-DG transfer, sensory developmental delay decreased by 2 times $(39.5 \%)$. Students with BMF in the experimental group were lagging behind in play activities compared with pre-recovery rates $(20.5 \%$ of such students before recovery), while $10.5 \%$ remained after the study, while the lag in skill acquisition was almost $70.0 \%$ before recovery, with only $18.4 \%$ remaining after the program.

In order to determine the effectiveness of the developed program, re-tests were conducted to study the physical fitness and functional performance of students with musculoskeletal disorders.

The results of a study of students with various musculoskeletal injuries showed that students 'physical fitness scores were 8.6 seconds after 12-14 sessions, compared to 9.2 seconds for the 30-meter running test. The final test result was 6.8 seconds. 
The dynamics of initial and final results improved by $26 \%$.

While the initial results of the $4 \times 10$ meter sprint test (seconds) were 23.2 seconds, the result was 18.2 after stage 1 . The final result of the study was 15.2 seconds. The dynamics of the indicators between the initial and final results was $34.4 \%$.

The initial results of the tests performed to determine the elasticity were $11 \mathrm{~cm}$, the arithmetic mean in stage 1 was $14 \mathrm{~cm}$, and the arithmetic mean after stage 2 was 18 $\mathrm{cm}$. The dynamics of indicators between the initial and final results improved by $63.6 \%$.
In the study of the hand flexion test, the initial results were 19 times, while the arithmetic mean in stage 1 was 25 times. In stage 2 , the arithmetic mean was 28 times. Between the initial and final results, the figures improved by $47.3 \%$.

While the initial results for the long jump (cm) test at the standing position were 174 $\mathrm{cm}$, after 12-14 sessions the result increased to $182 \mathrm{~cm}$. The final result was $199 \mathrm{~cm}$. The difference between the initial and final results improved by $14.3 \%$ (Table 4).

Table 4

Dynamics of growth of motor readiness indicators in students with various injuries of the musculoskeletal system

(nosological position in one leg and one $\operatorname{arm} \mathrm{TG} \mathrm{n}=44, \mathrm{NG} \mathrm{n}=38$ )

\begin{tabular}{|c|c|c|c|c|c|}
\hline Test & Group & $\begin{array}{l}\text { The } \\
\text { arithmetic } \\
\text { mean of the } \\
\text { initial results }\end{array}$ & $\begin{array}{l}\text { Lessons 14- } \\
16 \text { The } \\
\text { arithmetic } \\
\text { mean after }\end{array}$ & $\begin{array}{l}\text { The end } \\
\text { result } \\
\text { arithmetic } \\
\text { mean }\end{array}$ & $\begin{array}{l}\text { The change } \\
\text { between the } \\
\text { initial and } \\
\text { final result }\end{array}$ \\
\hline \multirow[b]{2}{*}{$\begin{array}{l}\text { Running } 30 \text { meters } \\
\text { (seconds) }\end{array}$} & $\mathrm{EG}$ & 9.2 & 8.6 & 6.8 & $26 \%$ \\
\hline & $\mathrm{CG}$ & 9.1 & 8.8 & 7.7 & $15.3 \%$ \\
\hline \multirow{2}{*}{$\begin{array}{lll}\text { Running } & 10 \quad x \quad 4 \\
\text { meters (seconds) }\end{array}$} & EG & 23.2 & 18.2 & 15.2 & $34.4 \%$ \\
\hline & CG & 24.1 & 22.6 & 21.3 & $11.6 \%$ \\
\hline \multirow{2}{*}{$\begin{array}{lr}\text { Leaning forward } \\
\text { from an upright } \\
\text { position }(\mathrm{sm}) & \\
\end{array}$} & EG & 11 & 14 & 18 & $63.6 \%$ \\
\hline & $\mathrm{CG}$ & 10 & 12 & 13 & $30 \%$ \\
\hline \multirow{2}{*}{$\begin{array}{l}\text { Bending the hand and } \\
\text { writing } \\
\text { (once) }\end{array}$} & EG & 19 & 25 & 28 & $47.3 \%$ \\
\hline & $\mathrm{CG}$ & 20 & 22 & 24 & $20 \%$ \\
\hline \multirow{2}{*}{ 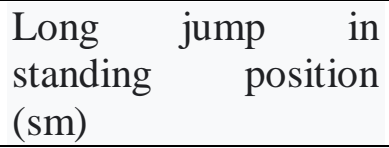 } & $\mathrm{EG}$ & 174 & 182 & 199 & $14.3 \%$ \\
\hline & $\mathrm{CG}$ & 173 & 176 & 179 & $3.4 \%$ \\
\hline
\end{tabular}

The Robinson Index, a reserve indicator, was used to qualitatively assess the energy supply of the human body. It was used to assess the level of metabolism and energy processes that take place in the body.

The Robinson index represents the systolic work of the heart. The higher this figure is at the height of physical activity, the better the functional capacity of the heart muscle. Depending on this indicator, it is possible to indirectly think about the oxygen demand of the myocardium.
To calculate the Robinson index, it is necessary to determine a person's heart rate and systolic blood pressure readings. The Robinson index was determined using the following formula:

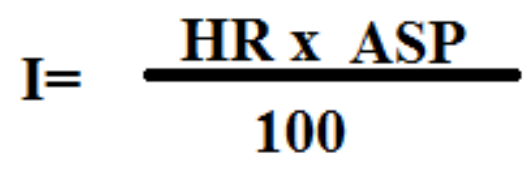

Here:

$\mathrm{I}=$ Robinson index, HR-heart rate, ASParterial systolic pressure.

Table 5 


\section{Evaluation table.}

\begin{tabular}{|l|l|}
\hline Status price & Robinson index \\
\hline $\begin{array}{l}\text { Excellent.! } \\
\text { The functional reserve of the cardiovascular } \\
\text { system is excellent. }\end{array}$ & 69 and below \\
\hline $\begin{array}{l}\text { Good! } \\
\text { The functional reserve of the cardiovascular } \\
\text { system is normal. }\end{array}$ & $70-84$ \\
\hline $\begin{array}{l}\text { Average! } \\
\text { It can be said that there is a deficiency in the } \\
\text { functional reserves of the cardiovascular } \\
\text { system. }\end{array}$ & $85-94$ \\
\hline $\begin{array}{l}\text { Bad! } \\
\text { There are signs of impairment in the } \\
\text { management of the activity of the } \\
\text { cardiovascular system. }\end{array}$ & $95-110$ \\
\hline $\begin{array}{l}\text { Too bad! } \\
\text { The activity of the cardiovascular system is } \\
\text { impaired. }\end{array}$ & 110 and higher \\
\hline
\end{tabular}

The results of the assessment of the energy potential of the body show that in $40-50 \%$ of students with musculoskeletal disorders improved reserve capacity in the functioning of the cardiovascular system (Figure 1).

From this it can be concluded that the program developed for students with musculoskeletal disorders and the methodology of their application show that they are effective.

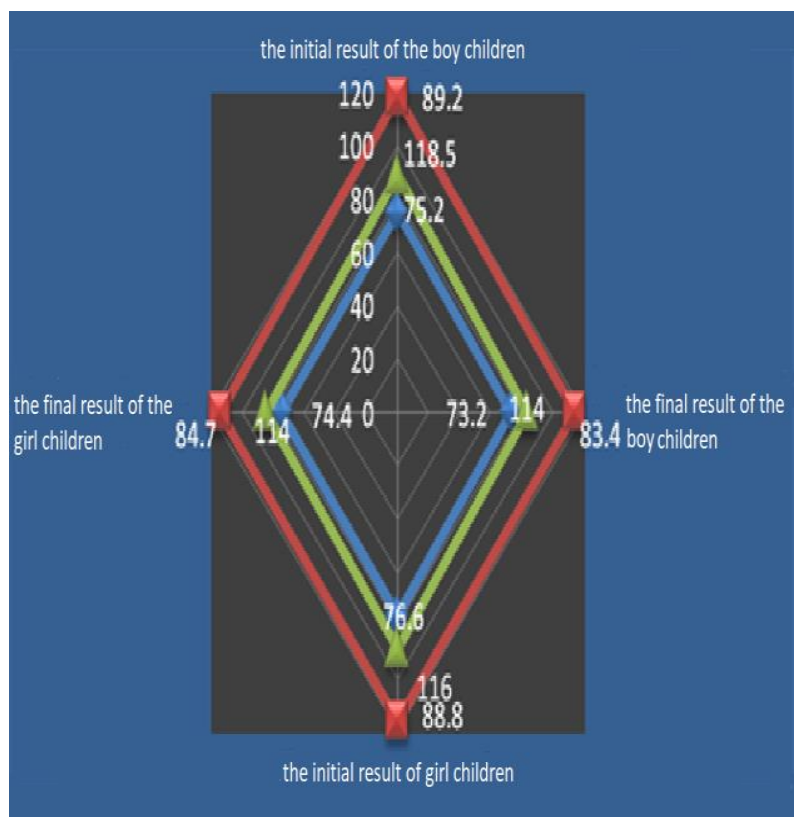

\begin{tabular}{|l|l|l|l|}
\hline Conditio & HR & ASP & Robinson index \\
\hline Boys are the first result & 75.2 & 118.5 & 89.2 \\
\hline The boys are the end result & 73.2 & 114 & 83.4 \\
\hline Girls are the first result & 76.6 & 116 & 88.8 \\
\hline Girls are the end result & 74.4 & 114 & 84.7 \\
\hline
\end{tabular}


Figure 1 Mean arithmetic mean of the final results on the Robinson index in students with musculoskeletal disorders

An individual approach was used at the beginning of the learning process. Over time, the individual method was transferred to the group method (groups should consist of 3-6 people). One type of group method was appropriate, in which students of the same level were selected for the group on physical development, BMF form, movement disorders of simultaneous appearances. Depending on the adaptation of the students, the groups were increased to 7-12 people (groupindividualized method). The basic rule of endurance training in students with disabilities is to gradually increase physical loads of varying intensity by engaging as many muscle groups as possible.

The development of general endurance served as the basis for the formation of specific types of physical qualities (strength, speed, reciprocity of movements, steady state, etc.). Baseline To develop the physical abilities of students with impaired function of movement limbs, they were taught to perform exercises for a relatively long period of time with continuous moderate intensity.

In improving the tools, methods and training rules and movements, teaching them solid skills and competencies, a stratified approach focused on using as much of the analyzer systems as possible, ensuring that a set of movement actions was performed and many movements were formed. Based on the data obtained, we can say with sufficient confidence about the great positive effect of exercise on the body of students, which not only allowed the general physical development of students, but, most importantly, activated the restorative functions of the sick limbs (compensatory mechanisms that allowed the arms to grow as long as the legs worked faster). Experiments have shown that a program designed to improve motor activity has been effective.

\section{CONCLUSIONS}

As a result of the analysis of data from all departments of our research, it was possible to draw the following conclusions:

1. The analysis of special scientific and methodological literature shows that the involvement of students with disabilities in active life, work through medical, social and vocational rehabilitation is a topical issue. The main group of individuals with musculoskeletal injuries is a severe disease of the nervous system, often leading to disability, according to literary sources..

2. The program, developed on the basis of experimental data, demonstrated the ability of the organism to adapt to different loads, forming on the basis of modern requirements for physical education. The following results were noted in the study:

The results of tests conducted to assess the energy potential of the body in students with musculoskeletal disorders, firstly, described the possibility of movement, on the other hand, while the ability to normalize the load in the classroom. Assessment results on the Robinson index In boys, at the beginning of the study, $10 \%$ of students recorded normative results according to the index score, while at the end of the study, the figure was $79.6 \%$. In girls, these indicators met the normative requirements in only $29.7 \%$ of students at the beginning of the study, while the study found that $74.4 \%$ of students met the normative requirements.

3. It was noted that after training aimed at developing physical qualities (especially in the arms and legs), the manifestation of rapid qualities in sick limbs as well as in healthy limbs. It should be noted that compensatory mechanisms were found to develop rapidly in patients with severe limb injuries. Indeed, after the experiment, the tepping-test increased rapid movements in the right leg 9.3 times, in the left leg 3.7 times in the standing position, and in the sitting position 7 times in the right leg, and 4.3 times in the left leg. In groups with moderate to mild 
injuries, a greater increase in rapid movements was reported after the experiment.

4. Thus, it should be noted that the exercises selected for the exercise not only served for physical development but also improved heart performance. With this in mind, it was found that training with students with disabilities had a positive effect on improving the balance between body systems and increasing mobility. The program developed by us confirms that the exercises used in it have a positive effect on the functional systems of the body, the processes of physical development and improvement.

\section{List of used literature}

1 Abele, A., 'Physical Education and Education through Sport in Latvia', in: G. Klein \& K. Hardman, Physical Education and Sport Education in the European Union, Paris, Editions Revue EP. S, (in press) 2004.

Астафьева Н. Г., Кобзев Ю. А., Храмов В. В. Оценка качества жизни лиц с физическими недостатками, занимающихся адаптивным спортом / Социология медицины. 2003. N 1. - С. 41-44.

西

Арипова В.Б., Адаптив жисмоний тарбиянинг копцептуал сохасининг илмий методик йўналишлари. Магистирлик диссертация Тошкент 2012 йил. 56-57б.

4

Armour, K. and Yelling, M., 'Continuing Professional Development for Experienced Physical Education Teachers: Towards Effective Provision', Sport, Education and Society, 9 (1), 2004, pp. 95-114.

Balz, E., \& Neumann, P., Physical Education in Germany', in: U. Puhse \& M. Gerber (Eds.), International Comparison of Physical Education, Concept - Problems - Prospects, Aachen, Meyer \& Meyer Verlag, pp. 292-309, 2005.

6 Боярская Л. А., Харитонова Л. Г. Особенности развития мануальной моторики у школьников с ограниченными возможностями. Вестник УГТУ-УПИ. Серия «Образование и воспитание. Экономика и управление физической культуры и спорта». Современные проблемы развития физической культуры в образовательном учреждении: Сб. науч. статей. Екатеринбург: ГОУ ВПО УГТУ-УПИ. Вып. 3 С. 246257, 2004.

Benn, T., 'Muslim Girls and participation in Physical Education', unpublished paper, November 2006. Pp 7-9.

Brandl-Bredenbeck, H. P, and Brettschneider, W. D., Societal Trends out of School of School Age Boys and Girls, unpublished Paper, January 2007.

9 Brettschneider, W-D., 'Psychological outcomes and social benefits of sport involvement and physical activity implications for physical education', in: G. Doll-Tepper \& D, Scoretz, Proceedings of The World Summit on Physical Education, Berlin, ICSSPE, 2001, pp. 77-82.

10 Carreiro da Costa, F., 'Physical Education in Portugal', in: U. Puhse, \& M. Gerber (Eds.). International Comparison of Physical Education, Concept - Problems - Prospects, Aachen, Meyer \& Meyer Verlag, 2005, pp. 554-571.

11 Crum, B., and Stegeman, H., 'The State of Physical Education in the Netherlands', in: U. Puhse \& M. Gerber (Eds.), International Comparison of Physical Education. Concept Problems -Prospects, Aachen, Meyer \& Meyer Verlag, 2005, pp. 460-471.

12 De Knop, P., Theeboom, M., Huts, K., et al., 'The state of school physical education in Belgium', in: U. Puhse \& M. Gerber (Eds.), International Comparison of Physical Education, Concept -Problems - Prospects, Aachen, Meyer \& Meyer Verlag, 2005, pp. 104-131. 
13 Девятова М.В. «Умуртка погонасининг бел остеохондрозида ДЖТ». Новосибирск, 1996 й.163-167 б.

Исмоилов Р.Т. Бошланғич синфларда жисмоний тарбия - соғломлаштириш тадбирларининг педагогик хусусиятлари. Афтореферат, Тошкент 2010 йил

Жукова О. Л., Еркомайшвили И. В., Сазонов А. История развития адаптивного спорта высших достижений слепых в Свердловской области

16 Основы управления специальным образованием: Учебное пособие для студентов вузов / Под пед. Д.С. Шилова.- М.: Академия, 2001.- 336 с.

17 Светличная Н.К. Основы адаптивного физического воспитания детей. - Т.: Иқтисодиёт, 2014. - 84 с.

18 Солодков А.С., Е.Б.Сологуб. Физиология человека. Общая. Спортивная. Возрастная - М.,2005.144-146 б.

19 Вестник УГТУ-УПИ. Серия «Образование и воспитание. Экономика и управление физической культуры и спорта». Современные проблемы развития физической культуры в образовательном учреждении: Сб. науч. статей. Екатеринбург: ГОУ ВПО УГТУ-УПИ. Вып. 3 С. 232-239, 2004.

20 Веневцев С. И. Адаптивный спорт для лиц с нарушениями интеллекта: Методическое пособие. Издательство Советский спорт, 2004. - Декларация о правах умственно отсталых лиц от 20 декабря 1971 г. (принята Генеральной Ассамблеей $\mathrm{OOH})$.

21 Виноградова А.С. Роль информации о болезни в системе реаблитации больных остреортрозом: дис...канд.мед.наук. Ярасловль,2005.-125 с.

22 Gapparov Z.G.,Ishtaev J.M., Ishtaev D.R., Holmurodov L.Z. Efficiency development explosive abilities at schoolboys of 12-13 years. Solid State technology // Volume: 63 Issue:4. Publication Year:2020. 